\title{
Performance and feeding behavior of dairy cows fed high-concentrate diets containing steam-flaked or ground corn varying in particle size
}

\author{
F. Ahmadi, ${ }^{1}$ G. R. Ghorbani, ${ }^{1 *}$ A. Sadeghi-Sefidmazgi, ${ }^{1}$ M. Heydari, ${ }^{1}$ H. Rafiee,${ }^{1 *}$ and K. A. Beauchemin ${ }^{2}$ \\ ${ }^{1}$ Department of Animal Sciences, College of Agriculture, Isfahan University of Technology, Isfahan 84156-83111, Iran \\ ${ }^{2}$ Lethbridge Research and Development Centre, Agriculture and Agri-Food Canada, Lethbridge, AB, Canada T1J 4B1
}

\begin{abstract}
Steam-flaked corn (SFC) and ground corn (GC) of different particle sizes were evaluated for their effects on dry matter intake (DMI), milk yield and components, chewing activity, ration sorting, ruminal fermentation, and digestibility in lactating dairy cows. Eight multiparous Holstein cows in mid-lactation $(46.6 \pm 3.5 \mathrm{~kg} / \mathrm{d}$ milk production and $101 \pm 10 \mathrm{~d}$ in milk) were used in a double $4 \times 4$ Latin square design with 21 -d periods. Cows were fed diets (dry matter basis) containing $36.2 \%$ forage (alfalfa hay and corn silage), $37.4 \%$ corn grain, and $26.4 \%$ other ingredients. The corn grain was ground (coarse: $1.08 \mathrm{~mm}$; medium: $0.84 \mathrm{~mm}$; and fine: $0.73 \mathrm{~mm}$ ) or steam-flaked (SFC; density $=0.40 \mathrm{~kg} / \mathrm{L}$ ). The dry matter proportion retained on an $8-\mathrm{mm}$ sieve was greater for the SFC diet than for the GC diets. There were no treatment effects on DMI, milk yield, fat-corrected milk, energy-corrected milk, fat or lactose yield, protein or lactose content, or milk urea nitrogen concentration. However, digestibility of dry matter and organic matter were greater for fine $\mathrm{GC}$ and $\mathrm{SFC}$ than the other diets. In addition, cows fed SFC had lower total-tract starch digestibility than cows fed GC diets. Cows fed SFC tended to have lower propionate proportion (22.8 vs. $27.1 \mathrm{mM}$ ) and total volatile fatty acid concentration (88.6 vs. $99.8 \mathrm{mM}$ ) in ruminal fluid than those fed GC diets. Acetate and butyrate concentration, acetate to propionate ratio, and ruminal concentration of ammonia-nitrogen were not affected by treatments. Ruminal $\mathrm{pH}(6.46$ vs. 6.01$)$ as well as milk fat content (2.75 vs. $2.59 \%$ ) and efficiencies (fatcorrected milk/DMI and energy-corrected milk/DMI) were greater for SFC than GC, regardless of its particle size. Milk fat content tended to increase linearly with increasing particle size of GC. Eating activity (min/d)
\end{abstract}

Received July 27, 2019

Accepted November 27, 2019.

*Corresponding authors: Ghorbani@cc.iut.ac.ir and hrafiee@alumni ut.ac.ir tended to be less for SFC compared with GC, but rumination activity $(\mathrm{min} / \mathrm{d})$ and total chewing activity (min/d) were not affected by processing or particle size. The results of study indicate that, compared with GC, steam flaking of corn with $400 \mathrm{~g} / \mathrm{L}$ density increased milk fat content and efficiency of high-producing dairy cows without any negative effect on milk yield. For GC, milk fat content tended to linearly increase and starch digestibility decreased linearly with increasing particle size.

Key words: starch digestibility, corn processing, milk fat content

\section{INTRODUCTION}

Low forage quality has led to increasing consumption of concentrates for dairy cattle in Iranian farms and elsewhere. High-producing cows receive grains, primarily corn, as the major source of energy in their diets. Approximately $75 \%$ of the energy from corn grain is derived from starch (NRC, 2001). Starch granules in corn grain are surrounded by a protein matrix in the endosperm that is largely resistant to microbial digestion unless processed (Kotarski et al., 1992; McAllister et al., 1994). Various techniques of processing cereal grains have been developed to increase their efficiency of use by dairy cows (McNiven et al., 1995), leading to improved lactational performance (Ferraretto et al., 2013). The effect of processing on ruminal degradation of starch varies among cereals and is dependent on the processing method used (Svihus et al., 2005).

The effect of corn particle size (PS) on starch digestibility is well known. Lykos and Varga (1995) in an in situ study found a linear inverse relationship between PS of ground corn (GC) and ruminal digestibility, and Ferraretto et al. (2013) in a meta-analysis reported that reducing the mean PS of GC (from 4,000 to $500 \mu \mathrm{m}$ ) increased total-tract starch digestibility (from 77.7 to 93.3\%). Large particles are resistant to water uptake and microbial degradation in the rumen and enzymatic digestion in the intestines. However, caution must be exercised when feeding finely GC to ruminants because 
the rapid rate of starch availability in the rumen increases the incidence of metabolic diseases, particularly ruminal acidosis (Owens and Zinn, 2005).

Steam flaking is another processing technique for optimizing starch utilization of corn by ruminants. Steam flaking increases starch digestibility because the moisture and heat applied during flaking disrupts the protein matrix surrounding the starch granules (Theurer et al., 1999). Diets consisting of steam-flaked corn (SFC) supply dairy cows more energy to support milk production compared with diets comprised of GC (Cooke et al., 2008). In addition, diets containing SFC have been shown to increase milk yield, milk protein yield, FCM, SNF, and lactose content when compared with diets containing corn processed using other methods (Oliveira et al., 1993; Chen et al., 1995). However, when corn is finely ground, differences between GC and SFC can be minimal, resulting in similar FCM yields (Mathew et al., 2011).

We hypothesized that reducing the PS of GC would increase total VFA concentration in ruminal fluid, digestibility in the total tract and milk yield by dairy cows, and cows fed finely GC and SFC would have similar performance and digestibility, and cows fed finely GC and SFC would sort in favor of long particles to attenuate SARA. The objective of this study was to determine the effects of diets containing SFC or GC varying in PS on the performance, ruminal characteristics, nutrient digestibility, and sorting index of highproducing dairy cows when fed high-concentrate diets.

\section{MATERIALS AND METHODS}

The experiment was conducted at Lavark Research Station, Isfahan University of Technology, Isfahan, Iran. The cows were cared for according to the guidelines of the Iranian Council of Animal Care (1995), and the experiment was approved by the Institutional Animal Care Committee for Animals Used in Research.

\section{Cows, Diets, and Management}

Eight multiparous Holstein cows (101 \pm 10 DIM, $\mathrm{BW}=607 \pm 62 \mathrm{~kg}$, milk yield $=46.6 \pm 3.5 \mathrm{~kg} / \mathrm{d}$; mean \pm SE at the start) were used in a double $4 \times$ 4 Latin square design consisting of 21 -d periods. The periods included $13 \mathrm{~d}$ of adaptation followed by $8 \mathrm{~d}$ for sampling and data collection. Cows within each square were randomly assigned to dietary sequences arranged to minimize carryover effects.

Throughout the experiment, the cows were housed individually in box stalls bedded with wood shavings. The experimental diets were prepared as TMR and offered twice daily at 0700 and $1800 \mathrm{~h}$ in amounts that allowed 5 to $10 \%$ refusal. Cows had free access to water. Dietary treatments were (1) FGC, TMR containing finely ground corn [average geometric mean particle size $($ GMPS $) \pm$ geometric standard deviation $=0.73 \pm$ $0.2 \mathrm{~mm}$ ]; (2) MGC, TMR containing medium ground corn $(0.84 \pm 0.28 \mathrm{~mm})$; (3) CGC, TMR containing coarse ground corn $(1.08 \pm 0.68 \mathrm{~mm})$; and (4) SFC, TMR containing SFC (density of $400 \mathrm{~g} / \mathrm{L}$ ). Ingredient composition and chemical composition of the diets are presented in Table 1. The forage:concentrate ratio was 36:64 on a DM basis, with corn silage and chopped alfalfa hay used as the forage components. Experimental diets were formulated using the Cornell Net Carbohydrate and Protein System (version 5.0) to meet the energy and protein requirements of cows (650 kg of BW, 100 DIM) producing $46.6 \mathrm{~kg} / \mathrm{d}$ of milk (3.2\% fat and $3.0 \%$ protein) and consuming $24.9 \mathrm{~kg} / \mathrm{d}$ DM. Mean DMI and milk yield were determined $14 \mathrm{~d}$ before the start of the study. Before feeding, alfalfa hay was chopped to a theoretical length of $30 \mathrm{~mm}$ using a harvesting machine equipped with a sieve size regulator (Golchin Trasher Hay Co., Isfahan, Iran). Corn silage was stored in a bunker silo and sampled on a weekly basis for DM content $\left(60^{\circ} \mathrm{C}\right.$ for $\left.48 \mathrm{~h}\right)$ with its inclusion in the TMR adjusted accordingly.

\section{Corn Processing}

The corn grain was processed at the Chavdaneh Plant, Isfahan, Iran. The corn was steam flaked in a vertical stainless steel chamber at $99^{\circ} \mathrm{C}$ for about 30 min, whereas moisture in the chamber was raised to $18 \%$ before the corn was passed through a pre-heated roller mill $(46 \times 90 \mathrm{~cm}$ in size $)$ to produce flakes with a density of $400 \mathrm{~g} / \mathrm{L}$. The flakes were bagged in plastic bags and sealed. Corn grains were ground using a hammer mill (model 5543 GEN, Isfahan Dasht, Isfahan, Iran) and passed through sieves with mesh sizes of 2, 3, and $4 \mathrm{~mm}$ for the FGC, MGC, and CGC, respectively.

\section{Geometric Mean Particle Size and Density}

The GMPS of the ground grains was measured using a dry sieving technique and automatic sieve shaker (Sieve Shaker, M. 120, Techno Khak, Khavaran, Tehran, Iran) with sieve diameters of 4.75, 2.36, 1.18, 0.85, $0.60,0.30,0.15,0.075 \mathrm{~mm}$ and a bottom pan (Table 2). Approximately $100 \mathrm{~g}$ of each sample was placed on the top sieve and the stack was shaken until the distribution of the materials did not change (approximately 10 min; ASABE, 2003, method S319.3). The GMPS and geometric standard deviation were calculated according to the equations given by ASABE (2003, method S319.3). 
Table 1. Ingredients and chemical composition of the experimental diets (mean $\pm \mathrm{SD}$ )

\begin{tabular}{|c|c|c|c|c|}
\hline \multirow[b]{2}{*}{ Item } & \multicolumn{4}{|c|}{$\operatorname{Diet}^{1}$} \\
\hline & FGC & MGC & CGC & $\mathrm{SFC}$ \\
\hline \multicolumn{5}{|l|}{ Ingredient, $\%$ of $\mathrm{DM}$} \\
\hline Alfalfa hay & 16.9 & 16.9 & 16.9 & 16.9 \\
\hline Corn silage & 19.3 & 19.3 & 19.3 & 19.3 \\
\hline Corn grain & 37.4 & 37.4 & 37.4 & 37.4 \\
\hline Beet pulp (pellet) & 1.61 & 1.61 & 1.61 & 1.61 \\
\hline Soybean meal, $48 \% \mathrm{CP}$ & 12.6 & 12.6 & 12.6 & 12.6 \\
\hline Soy pass & 5.63 & 5.63 & 5.63 & 5.63 \\
\hline Fish meal & 1.79 & 1.79 & 1.79 & 1.79 \\
\hline Fat powder ${ }^{2}$ & 2.21 & 2.21 & 2.21 & 2.21 \\
\hline Sodium bicarbonate & 0.72 & 0.72 & 0.72 & 0.72 \\
\hline Calcium carbonate & 0.44 & 0.44 & 0.44 & 0.44 \\
\hline Dicalcium phosphate & 0.18 & 0.18 & 0.18 & 0.18 \\
\hline Magnesium oxide & 0.24 & 0.24 & 0.24 & 0.24 \\
\hline Vitamin-mineral premix ${ }^{3}$ & 0.80 & 0.80 & 0.80 & 0.80 \\
\hline Salt & 0.20 & 0.20 & 0.20 & 0.20 \\
\hline \multicolumn{5}{|l|}{ Nutrient composition } \\
\hline DM, $\%$ as fed & $52.5 \pm 1.5$ & $52.7 \pm 1.35$ & $52.9 \pm 1.81$ & $52.9 \pm 1.21$ \\
\hline OM, $\%$ of DM & $92.2 \pm 0.29$ & $92.2 \pm 0.18$ & $92.2 \pm 0.18$ & $92.3 \pm 0.31$ \\
\hline $\mathrm{CP}, \%$ of $\mathrm{DM}$ & $17.2 \pm 0.48$ & $17.1 \pm 0.82$ & $17.5 \pm 0.55$ & $17.1 \pm 0.56$ \\
\hline NDF, $\%$ of DM & $34.2 \pm 0.48$ & $34.2 \pm 1.39$ & $33.6 \pm 1.15$ & $35.5 \pm 1.46$ \\
\hline Forage NDF, $\%$ of DM & 17.5 & 17.5 & 17.5 & 17.5 \\
\hline $\mathrm{ADF}, \%$ of $\mathrm{DM}$ & $15.2 \pm 0.97$ & $14.8 \pm 1.37$ & $15.0 \pm 1.57$ & $15.4 \pm 0.78$ \\
\hline Ether extract, \% of DM & $4.34 \pm 0.47$ & $4.56 \pm 0.32$ & $4.53 \pm 0.22$ & $4.63 \pm 0.82$ \\
\hline Starch, \% of DM & $29.7 \pm 0.22$ & $29.7 \pm 0.19$ & $30.0 \pm 20$ & $29.4 \pm 0.25$ \\
\hline Ash, \% of DM & $7.80 \pm 0.29$ & $7.80 \pm 0.18$ & $7.80 \pm 0.18$ & $7.70 \pm 0.31$ \\
\hline $\mathrm{NE}_{\mathrm{L}},{ }^{4} \mathrm{MJ} / \mathrm{kg}$ & 1.63 & 1.63 & 1.63 & 1.77 \\
\hline \multicolumn{5}{|c|}{$\begin{array}{l}{ }^{1} \text { Experimental diets contained fine-ground corn (FGC), medium-ground corn (MGC), coarse-ground corn } \\
(\mathrm{CGC}) \text {, and steam-flaked corn (SFC). }\end{array}$} \\
\hline \multicolumn{5}{|c|}{$\begin{array}{l}{ }^{2} \text { Containing fatty acids including C12:0 }(2 \mathrm{~g} / 100 \mathrm{~g} \text { of fatty acids }), \mathrm{C} 14: 0(5 \mathrm{~g} / 100 \mathrm{~g} \text { of fatty acids), C16:0 (80 } \\
\mathrm{g} / 100 \mathrm{~g} \text { of fatty acids), C18:0 (2 g/100 } \mathrm{g} \text { of fatty acids), C18:1 ( } 7 \mathrm{~g} / 100 \mathrm{~g} \text { of fatty acids), and C18:2 (3 g/100 } \\
\mathrm{g} \text { of fatty acids). }\end{array}$} \\
\hline \multicolumn{5}{|c|}{$\begin{array}{l}{ }^{3} \text { Containing (DM basis) } 1,300,000 \mathrm{IU} / \mathrm{kg} \text { of vitamin A, 360,000 IU } / \mathrm{kg} \text { of vitamin } \mathrm{D}_{3}, 12,000 \mathrm{IU} / \mathrm{kg} \text { of vitamin } \\
\mathrm{E}, 10 \mathrm{~g} / \mathrm{kg} \text { of manganese, } 16 \mathrm{~g} / \mathrm{kg} \text { of zinc, } 4 \mathrm{~g} / \mathrm{kg} \text { of copper; } 0.15 \mathrm{~g} / \mathrm{kg} \text { of iodine, } 0.12 \mathrm{~g} / \mathrm{kg} \text { of cobalt, } 0.8 \mathrm{~g} / \mathrm{kg} \\
\text { of iron, and } 0.08 \mathrm{mg} / \mathrm{kg} \text { of selenium. }\end{array}$} \\
\hline
\end{tabular}

Table 2. Distribution of ground corn grain particles on the sieves (\%)

\begin{tabular}{lccc}
\hline & \multicolumn{3}{c}{ Ground corn } \\
\cline { 2 - 4 } Item & FGC & MGC & CGC \\
\hline Sieve opening, mm & & & \\
4.75 & 0.4 & 0.2 & 0.4 \\
2.36 & 2.0 & 3.4 & 12.0 \\
1.18 & 2.8 & 5.6 & 30.1 \\
0.85 & 16.8 & 40.8 & 15.2 \\
0.6 & 59.3 & 36.3 & 26.6 \\
0.3 & 18.3 & 12.4 & 15.2 \\
0.15 & 0.3 & 1.2 & 0.4 \\
0.075 & 0.1 & 0.1 & 0.1 \\
Xgm, ${ }^{2}$ mm & 0.73 & 0.84 & 1.08 \\
SDgm, ${ }^{3}$ mm & 0.20 & 0.28 & 0.68 \\
\hline
\end{tabular}

${ }^{1}$ FGC: fine-ground corn; MGC: medium-ground corn; CGC: coarseground corn.

${ }^{2}$ Geometric mean particle size determined by ASABE (2003; method S319.3).

${ }^{3}$ Geometric standard deviation determined by ASABE (2003; method S319.3).
Bulk density of the GC was determined using a 100$\mathrm{mL}$ glass graduated cylinder. The cylinder was filled with sample, manually stirred, refilled, and stirred until a constant volume was obtained. The volume and weight of the sample were recorded, and the results were expressed as grams per milliliter. Bulk density was calculated by dividing the dry weight by volume (Theurer et al., 1999).

\section{Intake, Digestibility, and Analyses}

The feed offered and the orts for each cow were measured and sampled daily during the 8-d sample collection period and used to calculate DMI. The samples of forages were pooled within period, TMR was pooled by diet within period, and individual refusals were pooled by cow within period. Samples were frozen at $-20^{\circ} \mathrm{C}$ until analysis. The DM content of the feed and ort samples were determined after drying at $100^{\circ} \mathrm{C}$ in a forced- 
air oven for $24 \mathrm{~h}$ (AOAC International, 2002, method 925.40). The subsamples (dried in $60^{\circ} \mathrm{C}$ ) were subsequently ground to pass through a 1-mm sieve (Arthur H. Thomas, Philadelphia, PA) and analyzed for CP using the Kjeldahl method (Kjeltec 1030 Auto Analyzer, Tecator, Höganäs, Sweden; AOAC International, 2002, method 955.04), ether extract (AOAC International, 2002, method 920.39), ash (AOAC International, 2002, method 942.05), and NDF using heat-stable $\alpha$-amylase $(100 \mu \mathrm{L} / 0.5 \mathrm{~g}$ of sample, Van Soest et al., 1991). Total starch was measured using a modification (Zhu et al., 2016) of the glucoamylase method described by Mason et al. (1982).

Fecal samples were obtained from each cow over a period of $72 \mathrm{~h}$ beginning at $1700 \mathrm{~h}$ on $\mathrm{d} 16$ at 9 -h intervals as follows: $1700,0200,1100,2000,0500,1400,2300$, and $0800 \mathrm{~h}$. The samples were collected and composited by cow and kept frozen at $-20^{\circ} \mathrm{C}$ until analysis. Subsequently, they were dried in a forced-air oven at $60^{\circ} \mathrm{C}$ for $72 \mathrm{~h}$, ground to pass through a $1-\mathrm{mm}$ sieve, and analyzed for DM as described for feeds and orts. Apparent total-tract digestibilities of nutrients were calculated using the procedure of Van Keulen and Young (1977) with acid-insoluble ash as an internal marker.

\section{Milk Production, Composition, and Analyses}

Cows were milked 3 times daily at 0100, 0900, and 1700 h. Milk yields were recorded and averaged to determine the mean milk production for the entire period. At each milking during the 5-d sampling period, samples were collected and analyzed daily for fat, true protein, lactose, and total SNF (MilkoScan 134 BN, Foss Electric, Hillerød, Denmark; AOAC International, 2002, method 972.16). The MUN concentration was determined enzymatically (Wilson et al., 1998). Yield of each milk component was calculated at each milking and summed by sampling day and then averaged across sampling days. Yields of 3.5\% FCM and ECM were calculated according to the equations below:

$$
\begin{gathered}
\text { 3.5\% FCM }(\mathrm{kg} / \mathrm{d})=0.4324(\mathrm{~kg} / \mathrm{d} \text { of milk }) \\
+16.216(\mathrm{~kg} / \mathrm{d} \text { of fat })(\text { Wilson et al., 1998) }, \\
\text { ECM }(\mathrm{kg} / \mathrm{d})=12.82 \times \text { fat yield, } \mathrm{kg} / \mathrm{d} \\
\quad+7.13 \times \text { protein yield, } \mathrm{kg} / \mathrm{d} \\
+0.323 \times \text { milk yield, } \mathrm{kg} / \mathrm{d}(\text { Tyrrell and Reid, 1965) }
\end{gathered}
$$

Feed efficiency was calculated by dividing the actual milk yield, $3.5 \%$ FCM, and ECM production $(\mathrm{kg} / \mathrm{d})$ by DMI $(\mathrm{kg} / \mathrm{d})$.

\section{Ruminal Fermentation and Analyses}

On d 21 of each period, ruminal fluid samples (about 3 $\mathrm{mL}$ ) were collected from the ventral sac of each cow 3 to $4 \mathrm{~h}$ after the morning feeding, using the rumenocentesis technique described by Nordlund and Garrett (1994) as implemented by Nasrollahi et al. (2017). The pH was determined immediately after collection using a digital pH meter (HI 8318, Hanna Instruments, Cluj-Napoca, Romania) and the samples were immediately frozen at $-18^{\circ} \mathrm{C}$. The ruminal fluid samples were thawed and ruminal ammonia-nitrogen $\left(\mathrm{NH}_{3}-\mathrm{N}\right)$ concentration was determined using the colorimetric phenol-hypochlorite method of Broderick and Kang (1980). The ruminal fluid samples for VFA analysis were thawed and centrifuged at $10,000 \times g$ at $4^{\circ} \mathrm{C}$ for $20 \mathrm{~min}$ and analyzed for VFA using GC $(0.25 \times 0.32,0.3 \mu \mathrm{m}$ i.d. fused silica capillary, model no. CP-9002 Vulcanusweg 259 a.m., Chrompack, Delft, the Netherlands), as described by Bal et al. (2000).

\section{Chewing Activity}

Chewing activity was monitored over a 48-h period on d 19 and 20 of each period. Cows were observed for eating and ruminating activity every $5 \mathrm{~min}$ and the behavior performed at that time was recorded and assumed to last for the full $5 \mathrm{~min}$ (Beauchemin and Yang, 2005). Total chewing was the sum of eating and ruminating activity. Rumination bouts were defined as active ruminating activity, with a period of inactivity of $\geq 5$ min signifying the end of a rumination bout. Activities per kilogram of nutrient ingested, such as DM and NDF, were calculated by dividing total time spent for chewing, eating, or ruminating by d-20 intakes.

\section{Particle Size Distribution of the TMR, Orts, Forages, and Sorting Behavior}

A Penn State Particle Separator with 3 sieves (aperture sizes of 19.0, 8.0, and $1.18 \mathrm{~mm}$ ) was used to determine the PS distributions of the TMR and orts samples as described by Kononoff et al. (2003) (Table $3)$. The mean intake of each period and mean chewing times were used to estimate the time spent eating and ruminating per kilogram of DM and NDF intake. The sorting index was calculated as the ratio of actual intake to predicted intake of particles retained on each sieve of the separator at 4,6 , and $24 \mathrm{~h}$ after the TMR was delivered. A sorting index value above 100 indicates sorting for particles, and a value below 100 indicates sorting against particles (Leonardi and Armentano, 2003). 


\section{Statistical Analysis}

Data were averaged for each cow within period and analyzed using the mixed model procedure in SAS (version 9.1, SAS Institute Inc., Cary, NC). Square, period within square, and diet were considered as fixed effects in the model. Cow within square was specified as a random effect. The method of estimating LSM was maximum likelihood, and the Kenward-Roger method was used to calculate denominator degrees of freedom. The following statistical model was used for the analyses:

$$
\mathrm{Y}_{\mathrm{ij}(\mathrm{k}) \mathrm{m}}=\mu+\mathrm{S}_{\mathrm{m}}+\mathrm{P}(\mathrm{S})_{\mathrm{im}}+\mathrm{A}(\mathrm{S})_{\mathrm{jm}}+\mathrm{T}_{\mathrm{k}}+\mathrm{e}_{\mathrm{ij}(\mathrm{k}) \mathrm{m}},
$$

where $Y_{\mathrm{ij}(\mathrm{k}) \mathrm{m}}$ represents each observation, $\mu$ is the overall mean, $\mathrm{S}_{\mathrm{m}}$ is the fixed effect of square $\mathrm{m}, \mathrm{P}(\mathrm{S})_{\mathrm{im}}$ denotes the fixed effect of period $\mathrm{i}$ within square $\mathrm{m}$, $\mathrm{A}(\mathrm{S})_{\mathrm{jm}}$ denotes the random effect of cow $\mathrm{j}$ within square $\mathrm{m}$, $\mathrm{T}_{\mathrm{k}}$ is the fixed effect of treatment $\mathrm{k}$, and $\mathrm{e}_{\mathrm{ij}(\mathrm{k}) \mathrm{m}}$ is the residual. Data were tested for normality of distribution by Proc Univariate of SAS before analysis. Polynomial orthogonal contrasts were used to test the linear and quadratic effects of increasing PS of the GC (FGC, MGC, and CGC) using PROC IML of SAS, with coefficients adjusted to represent the unequally spaced GMPS. The differences among the treatments were compared using the Tukey multiple comparison test. Statistical significance of main effects was declared at $P$ $<0.05$, and tendencies were stated at $0.05 \leq P \leq 0.10$.

\section{RESULTS}

\section{Particle Size Distribution}

Nutrient composition was relatively similar across diets, and $\mathrm{NE}_{\mathrm{L}}$ concentration of the diet with $\mathrm{SFC}$ corn was numerically greater than that of the GC diets $(1.77$ vs. $1.63 \mathrm{Mcal} / \mathrm{kg}$ of DM; NRC, 2001). The average GMPS obtained for FGC, MGC, and CGC, respectively, was $0.73 \pm 0.20,0.84 \pm 0.28$, and $1.08 \pm 0.68$ $\mathrm{mm}$ (Table 2). Consequently, the GMPS of the TMR differed due to grain processing (Table 3): 3.32, 3.52,

Table 3. Effects of corn grain processing on diet particle size distribution (\% DM retained on each sieve) at 0, 2, 4, 6, and 24 h after feeding (8 cows/treatment)

\begin{tabular}{|c|c|c|c|c|c|c|c|c|}
\hline \multirow[b]{2}{*}{ Item } & \multicolumn{4}{|c|}{$\operatorname{Diet}^{1}$} & \multirow[b]{2}{*}{ SEM } & \multicolumn{3}{|c|}{$P$-value } \\
\hline & FGC & MGC & CGC & $\mathrm{SFC}$ & & Linear & Quadratic & Contrast $^{2}$ \\
\hline \multicolumn{9}{|c|}{$>19 \mathrm{~mm}$} \\
\hline $0 \mathrm{~h}$ & $6.83^{\mathrm{a}}$ & $7.64^{\mathrm{a}}$ & $7.21^{\mathrm{a}}$ & $5.53^{\mathrm{b}}$ & 0.88 & 0.57 & 0.14 & 0.004 \\
\hline $2 \mathrm{~h}$ & 10.5 & 9.18 & 13.1 & 12.4 & 1.74 & 0.23 & 0.31 & 0.48 \\
\hline $4 \mathrm{~h}$ & 11.9 & 9.32 & 14.6 & 10.2 & 2.66 & 0.38 & 0.29 & 0.57 \\
\hline \multicolumn{9}{|l|}{$>8 \mathrm{~mm}$} \\
\hline $0 \mathrm{~h}$ & $19.9^{\mathrm{b}}$ & $20.1^{\mathrm{b}}$ & $20.2^{\mathrm{b}}$ & $37.4^{\mathrm{a}}$ & 0.59 & 0.57 & 0.95 & $<0.001$ \\
\hline $2 \mathrm{~h}$ & $20.6^{\mathrm{b}}$ & $19.9^{\mathrm{b}}$ & $20.1^{\mathrm{b}}$ & $34.9^{\mathrm{a}}$ & 0.84 & 0.72 & 0.69 & $<0.001$ \\
\hline $4 \mathrm{~h}$ & $20.6^{\mathrm{b}}$ & $20.5^{\mathrm{b}}$ & $20.3^{\mathrm{b}}$ & $35.1^{\mathrm{a}}$ & 1.13 & 0.86 & 0.98 & $<0.001$ \\
\hline $6 \mathrm{~h}$ & $23.0^{\mathrm{b}}$ & $22.6^{\mathrm{b}}$ & $22.9^{\mathrm{b}}$ & $36.6^{\mathrm{a}}$ & 1.53 & 0.97 & 0.85 & $<0.001$ \\
\hline $24 \mathrm{~h}$ & $24.2^{\mathrm{c}}$ & $27.2^{\mathrm{bc}}$ & $27.7^{\mathrm{b}}$ & $35.0^{\mathrm{a}}$ & 1.92 & 0.05 & 0.23 & $<0.001$ \\
\hline \multicolumn{9}{|l|}{$>1.18 \mathrm{~mm}$} \\
\hline \multicolumn{9}{|l|}{ Pan } \\
\hline $0 \mathrm{~h}$ & $32.7^{\mathrm{a}}$ & $30.2^{\mathrm{a}}$ & $26.9^{\mathrm{b}}$ & $12.1^{\mathrm{c}}$ & 1.13 & $<0.001$ & 0.76 & $<0.001$ \\
\hline $2 \mathrm{~h}$ & $29.5^{\mathrm{a}}$ & $28.0^{\mathrm{a}}$ & $23.7^{\mathrm{b}}$ & $10.3^{\mathrm{c}}$ & 0.91 & 0.002 & 0.54 & $<0.001$ \\
\hline $4 \mathrm{~h}$ & $29.7^{\mathrm{a}}$ & $30.7^{\mathrm{a}}$ & $25.2^{\mathrm{b}}$ & $11.2^{\mathrm{c}}$ & 1.50 & 0.02 & 0.13 & $<0.001$ \\
\hline $6 \mathrm{~h}$ & $27.9^{\mathrm{a}}$ & $28.7^{\mathrm{a}}$ & $21.3^{\mathrm{b}}$ & $10.8^{\mathrm{c}}$ & 2.07 & 0.01 & 0.14 & $<0.001$ \\
\hline $24 \mathrm{~h}$ & $21.7^{\mathrm{a}}$ & $19.1^{\mathrm{ab}}$ & $16.2^{\mathrm{b}}$ & $8.36^{\mathrm{c}}$ & 2.41 & 0.007 & 0.74 & $<0.001$ \\
\hline $\mathrm{Xgm},{ }^{4} \mathrm{~mm}$ & $3.32^{\mathrm{c}}$ & $3.52^{\mathrm{bc}}$ & $3.66^{\mathrm{b}}$ & $5.41^{\mathrm{a}}$ & 0.15 & 0.04 & 0.59 & $<0.001$ \\
\hline $\mathrm{SDgm},{ }^{5} \mathrm{~mm}$ & $3.13^{\mathrm{c}}$ & $3.11^{\mathrm{bc}}$ & $2.99^{\mathrm{b}}$ & $2.60^{\mathrm{a}}$ & 0.07 & 0.01 & 0.44 & $<0.001$ \\
\hline
\end{tabular}

${ }^{\mathrm{a}-\mathrm{c}}$ Least squares means within a row with different superscripts differ significantly $(P<0.05)$.

${ }^{1}$ Experimental diets contained fine-ground corn (FGC), medium-ground corn (MGC), coarse-ground corn (CGC), and steam-flaked corn (SFC). ${ }^{2}$ Contrast $P$-value $=$ effects of ground corn versus SFC.

${ }^{3}$ A Penn State Particle Separator with 3 sieves was used to determine the particle size distributions as described by Kononoff et al. (2003).

${ }^{4}$ Geometric mean particle size as calculated by the American National Standards Institute (ANSI, 1995; method S424.1).

${ }^{5}$ Geometric standard deviation determined by ANSI (1995; method S424.1). 
Table 4. Effects of corn grain processing on nutrient intakes of lactating Holstein cows (8 cows/treatment)

\begin{tabular}{|c|c|c|c|c|c|c|c|c|}
\hline \multirow[b]{2}{*}{ Intake, $\mathrm{kg} / \mathrm{d}$} & \multicolumn{4}{|c|}{$\operatorname{Diet}^{1}$} & \multirow[b]{2}{*}{ SEM } & \multicolumn{3}{|c|}{$P$-value } \\
\hline & FGC & MGC & CGC & $\mathrm{SFC}$ & & Linear & Quadratic & Contrast $^{2}$ \\
\hline$\overline{\mathrm{DM}}$ & 25.4 & 25.3 & 25.4 & 24.6 & 0.85 & 0.99 & 0.84 & 0.17 \\
\hline $\mathrm{OM}$ & 23.2 & 23.1 & 23.3 & 22.6 & 0.75 & 0.89 & 0.83 & 0.25 \\
\hline Ether extract & 1.10 & 1.15 & 1.15 & 1.14 & 0.03 & 0.17 & 0.20 & 0.87 \\
\hline NDF & 8.86 & 8.82 & 8.83 & 8.58 & 0.38 & 0.96 & 0.94 & 0.44 \\
\hline Forage NDF & 4.46 & 4.43 & 4.45 & 4.32 & 0.15 & 0.98 & 0.83 & 0.17 \\
\hline $\mathrm{ADF}$ & 3.76 & 3.62 & 3.68 & 3.70 & 0.12 & 0.67 & 0.36 & 0.88 \\
\hline Starch & 7.56 & 7.52 & 7.62 & 7.25 & 0.25 & 0.25 & 0.22 & 0.06 \\
\hline \multicolumn{9}{|l|}{ TMR DMI } \\
\hline $2 \mathrm{~h}$ after feeding & 6.34 & 6.46 & 7.02 & 6.16 & 0.55 & 0.37 & 0.84 & 0.49 \\
\hline $4 \mathrm{~h}$ after feeding & 8.14 & 8.02 & 8.55 & 7.76 & 0.51 & 0.52 & 0.66 & 0.42 \\
\hline $6 \mathrm{~h}$ after feeding & 9.62 & 9.48 & 10.11 & 8.97 & 0.57 & 0.54 & 0.67 & 0.27 \\
\hline
\end{tabular}

${ }^{1}$ Experimental diets contained fine-ground corn (FGC), medium-ground corn (MGC), coarse-ground corn (CGC), and steam-flaked corn (SFC).

${ }^{2}$ Contrast $P$-value $=$ effects of ground corn versus SFC.

3.66, and $5.41 \mathrm{~mm}$ for FGC, MGC, CGC, and SFC diets, respectively. The DM proportion retained on the 19-mm sieve was less for the SFC diet than for the GC diets during the first hour after feeding $(P=0.004)$, but no differences were observed thereafter. The DM proportion retained on the 8-mm sieve was greater for the SFC diet than for the GC diets at $0,2,4,6$ and 24 $\mathrm{h}$ after feeding $(P<0.001)$. Also, the DM proportion retained on the $1.18-\mathrm{mm}(P<0.001)$ sieve increased 0 and $24 \mathrm{~h}$ after feeding the SFC diet compared with GC diets and it increased linearly at $0 \mathrm{~h}$ with increasing PS of GC. Proportion of DM on the pan was less for cows fed SFC than those on GC $\operatorname{diets}(P<0.001)$ at all times after feeding and it decreased with increasing PS of GC.

\section{Nutrient Intakes and Sorting}

Intakes of $\mathrm{DM}, \mathrm{OM}$, NDF, forage $\mathrm{NDF}$, and $\mathrm{ADF}$ were similar for all treatments and no differences were observed among diets for DMI at 2, 4, and $6 \mathrm{~h}$ after feeding (Table 4). Cows on all diets sorted against long particles $(>19 \mathrm{~mm})$ when examined over the entire $24-\mathrm{h}$ period (Table 5), with no differences due to diet. Unlike the cows fed GC diets, those fed the SFC diet sorted for medium-length particles $(>8 \mathrm{~mm})$ at $6(P=0.04)$ and

Table 5. Effects of corn grain processing on percentage selection of TMR from different sieves at 4, 6, and 24 $\mathrm{h}$ after feeding ( 8 cows/treatment)

\begin{tabular}{|c|c|c|c|c|c|c|c|c|}
\hline \multirow[b]{2}{*}{ Sieve $^{1}$} & \multicolumn{4}{|c|}{ Diet $^{2}$} & \multirow[b]{2}{*}{ SEM } & \multicolumn{3}{|c|}{$P$-value } \\
\hline & FGC & MGC & CGC & SFC & & Linear & Quadratic & Contrast $^{3}$ \\
\hline \multicolumn{9}{|l|}{$19 \mathrm{~mm}$} \\
\hline $4 \mathrm{~h}$ & 81.7 & 75.2 & 82.2 & 48.6 & 14.10 & 0.93 & 0.74 & 0.11 \\
\hline $6 \mathrm{~h}$ & 96.9 & 88.7 & 90.1 & 63.6 & 9.68 & 0.03 & 0.62 & 0.65 \\
\hline $24 \mathrm{~h}$ & 85.3 & 80.7 & 83.4 & 77.0 & 5.71 & 0.82 & 0.51 & 0.27 \\
\hline \multicolumn{9}{|l|}{$8 \mathrm{~mm}$} \\
\hline $4 \mathrm{~h}$ & 98.6 & 102.4 & 103.1 & 106.0 & 4.90 & 0.52 & 0.70 & 0.38 \\
\hline $6 \mathrm{~h}$ & 96.8 & 95.7 & 99.1 & 101.9 & 2.17 & 0.32 & 0.41 & 0.04 \\
\hline $24 \mathrm{~h}$ & $98.3^{\mathrm{b}}$ & $98.2^{\mathrm{b}}$ & $98.1^{\mathrm{b}}$ & $100.7^{\mathrm{a}}$ & 0.70 & 0.69 & 0.94 & 0.006 \\
\hline \multicolumn{9}{|c|}{$1.18 \mathrm{~mm}$} \\
\hline $4 \mathrm{~h}$ & 102.2 & 102.9 & 103.0 & 102.2 & 1.81 & 0.77 & 0.82 & 0.80 \\
\hline $6 \mathrm{~h}$ & 97.5 & 107.0 & 97.7 & 102.3 & 2.00 & 0.70 & 0.08 & 0.17 \\
\hline $24 \mathrm{~h}$ & 101.7 & 101.2 & 101.7 & 101.8 & 0.52 & 0.69 & 0.14 & 0.36 \\
\hline \multicolumn{9}{|l|}{ Pan } \\
\hline $4 \mathrm{~h}$ & 101.8 & 97.5 & 96.8 & 103.5 & 3.59 & 0.35 & 0.57 & 0.24 \\
\hline $6 \mathrm{~h}$ & 102.8 & 100.6 & 106.8 & 104.5 & 2.88 & 0.16 & 0.19 & 0.69 \\
\hline $24 \mathrm{~h}$ & 102.3 & 102.0 & 102.1 & 102.6 & 0.67 & 0.68 & 0.55 & 0.27 \\
\hline
\end{tabular}

$\overline{\mathrm{a}, \mathrm{b}}$ Least squares means within a row with different superscripts differ significantly $(P<0.05)$.

${ }^{1}$ The sorting index was calculated as described by Leonardi and Armentano (2003).

${ }^{2}$ Experimental diets contained fine-ground corn (FGC), medium-ground corn (MGC), coarse-ground corn (CGC), and steam-flaked corn (SFC).

${ }^{3}$ Contrast $P$-value $=$ effects of ground corn versus SFC. 
Table 6. Effects of corn grain processing on chewing activity of lactating Holstein cows (8 cows/treatment)

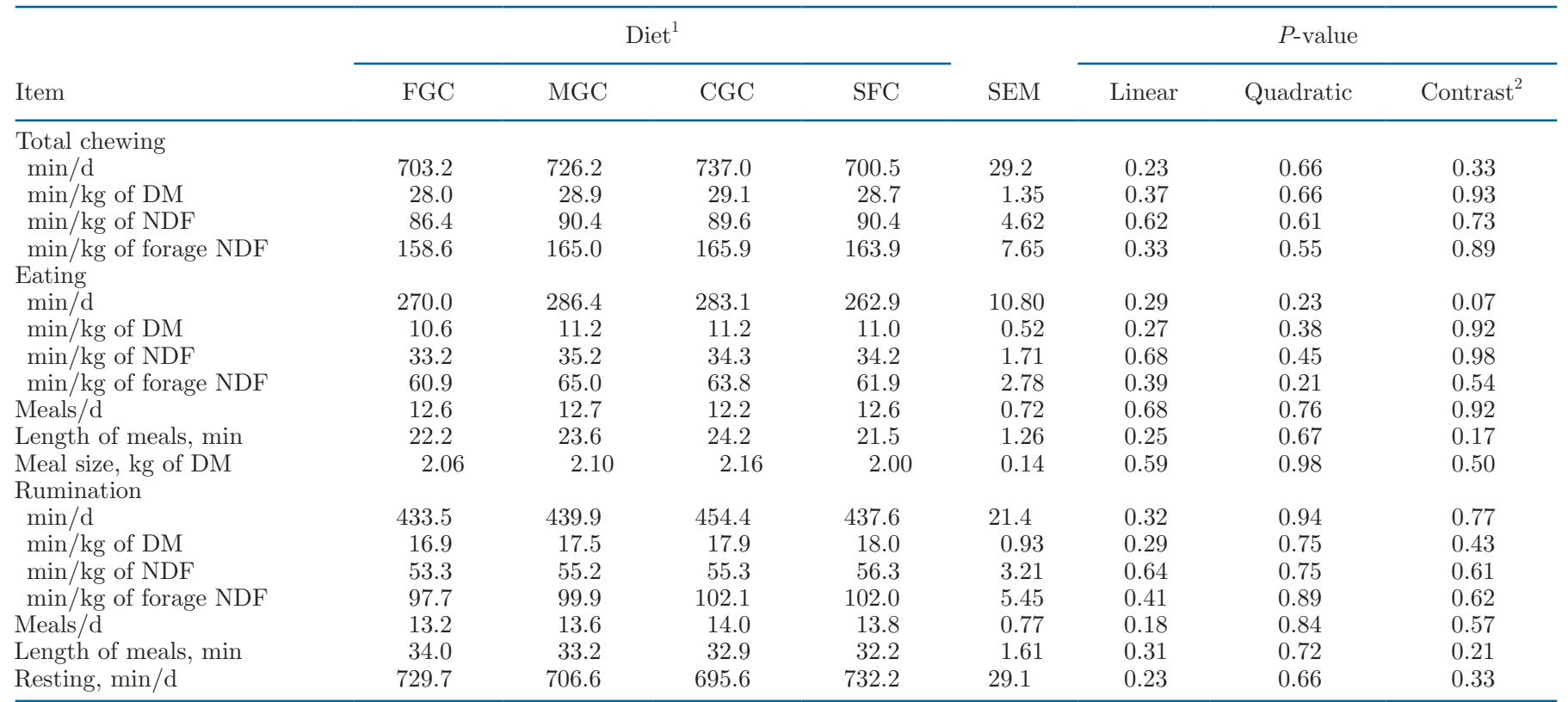

${ }^{1}$ Experimental diets contained fine-ground corn (FGC), medium-ground corn (MGC), coarse-ground corn (CGC), and steam-flaked corn (SFC).

${ }^{2}$ Contrast $P$-value $=$ effects of ground corn versus SFC.

$24(P=0.006) \mathrm{h}$ after feeding. No dietary differences were observed for selection of short particles $(1.18 \mathrm{~mm}$ and pan); cows on all diets sorted for short particles.

\section{Chewing Activity}

Type of processing or PS of GC did not affect total chewing time $(P \geq 0.45$; Table 6$)$. However, a tendency was observed for cows to spend less time eating per day when fed SFC compared with GC diets $(P=0.07)$. Eating time per kilogram of DM, NDF intake, and forage NDF intake were not influenced by grain processing. Ruminating time $(\mathrm{min} / \mathrm{d})$ was not affected by diet
$(P=0.77)$, even when expressed on the basis of NDF and forage NDF intakes. Finally, diet had no effects on number of meals or ruminating bouts $(P \geq 0.52)$. Resting time was also not affected $(P=0.45)$.

\section{Ruminal $\mathrm{pH}$ and Fermentation Characteristics}

Ruminal $\mathrm{pH}$ was greater for SFC than for $\mathrm{GC}$ diets (6.46 vs. $6.01 ; P=0.003$; Table 7 ), with no differences among GC diets. Total VFA concentration in ruminal fluid was lower for SFC than GC diets (88.6 vs. 99.8 $\mathrm{m} M ; P=0.05)$, also with no differences due to PS of GC diets $(P=0.98)$. Proportion of propionate tended

Table 7. Effects of corn grain processing on ruminal $\mathrm{pH}$ and ruminal fermentation of lactating Holstein cows (8 cows/treatment)

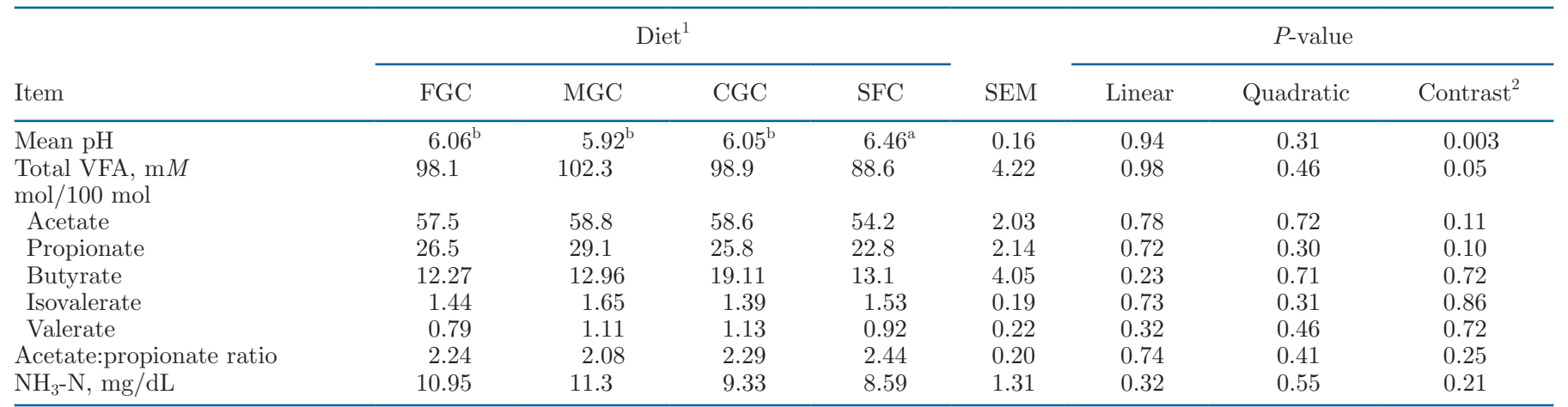

${ }_{\mathrm{a}, \mathrm{b}}$ Least squares means within a row with different superscripts differ significantly $(P<0.05)$.

${ }^{1}$ Experimental diets contained fine-ground corn (FGC), medium-ground corn (MGC), coarse-ground corn (CGC), and steam-flaked corn (SFC). ${ }^{2}$ Contrast $P$-value $=$ effects of ground corn versus SFC. 
Table 8. Effects of corn grain processing on milk yield and milk composition of lactating Holstein cows (8 cows/treatment)

\begin{tabular}{|c|c|c|c|c|c|c|c|c|}
\hline Item & \multicolumn{4}{|c|}{$\operatorname{Diet}^{1}$} & SEM & \multicolumn{3}{|c|}{$P$-value } \\
\hline Milk & 46.3 & 48.0 & 46.9 & 46.4 & 1.50 & 0.76 & 0.13 & 0.46 \\
\hline $3.5 \%$ FCM & 39.5 & 39.9 & 40.6 & 40.3 & 1.20 & 0.23 & 0.96 & 0.69 \\
\hline ECM & 39.9 & 40.6 & 40.9 & 40.6 & 1.10 & 0.31 & 0.74 & 0.89 \\
\hline Fat & 1.20 & 1.19 & 1.26 & 1.25 & 0.06 & 0.11 & 0.32 & 0.33 \\
\hline SNF & 3.40 & 3.52 & 3.45 & 3.39 & 0.10 & 0.68 & 0.15 & 0.29 \\
\hline \multicolumn{9}{|c|}{ Milk composition, $\%$} \\
\hline Fat & $2.61^{\mathrm{b}}$ & $2.48^{\mathrm{c}}$ & $2.70^{\mathrm{ab}}$ & $2.75^{\mathrm{a}}$ & 0.17 & 0.07 & 0.01 & 0.007 \\
\hline Protein & 2.91 & 2.91 & 2.90 & 2.91 & 0.02 & 0.34 & 0.40 & 0.86 \\
\hline Lactose & 4.70 & 4.71 & 4.69 & 4.69 & 0.04 & 0.62 & 0.52 & 0.71 \\
\hline SNF & 7.35 & 7.36 & 7.33 & 7.34 & 0.05 & 0.59 & 0.36 & 0.75 \\
\hline $\mathrm{NE}_{\mathrm{L}}, \mathrm{Mcal} / \mathrm{d}$ & 36.4 & 37.0 & 37.3 & 36.9 & 1.02 & 0.30 & 0.75 & 0.91 \\
\hline
\end{tabular}

${ }^{\mathrm{a}-\mathrm{c}}$ Least squares means within a row with different superscripts differ significantly $(P<0.05)$.

${ }^{1}$ Experimental diets contained fine-ground corn (FGC), medium-ground corn (MGC), coarse-ground corn (CGC), and steam-flaked corn (SFC).

${ }^{2}$ Contrast $P$-value $=$ effects of ground corn versus SFC.

to be lower for SFC than GC diets (22.8 vs. $27.1 \mathrm{~m} M ; P$ $=0.10)$, but no differences were observed among diets for the other individual VFA, acetate:propionate ratio, or $\mathrm{NH}_{3}-\mathrm{N}$ concentration.

\section{Milk Yield and Milk Composition}

Milk yield, 3.5\% FCM, and ECM were not different among the diets (Table 8). Protein content quadratically increased with processing of $\mathrm{GC}$ with greatest value for $\operatorname{MGC}(P=0.03)$. Lactose, $\mathrm{SNF}$, and $\mathrm{NE}_{\mathrm{L}}$ concentrations were not affected by diets. Milk fat content was greater for SFC than for GC diets (2.75 vs. $2.59 \% ; P=0.007)$. Finally, neither corn processing method $(P=0.14)$ nor corn PS $(P=0.83)$ influenced MUN concentration.

\section{Digestibility and Efficiency}

Digestibilities of DM and OM were greater for SFC than $\mathrm{GC}$ diets $(P \leq 0.01$; Table 9$)$ and starch digestibility was greater in GC diets than SFC (97.8 vs. $96.3 \% ; P=0.02)$. In addition, starch digestibility of the GC diets decreased linearly as corn PS increased $(P$ $=0.01$ ). However, for the GC diets, the digestibilities followed a quadratic pattern with PS such that DM digestibility was greatest for FGC and similar for MGC and $\mathrm{CGC}$, whereas $\mathrm{OM}$ digestibility was greatest for FGC and CGC, and lowest for MGC. Diet had no effect $(P=0.28)$ on feed efficiency measured as milk yield/ DMI. However, cows fed SFC had greater FCM/DMI and ECM/DMI than cows fed GC $(P \leq 0.04)$, with no differences among GC diets.

Table 9. Effects of corn processing on digestibility, feed efficiency, rectal temperature, and respiration rate of lactating Holstein cows (8 cows/treatment)

\begin{tabular}{|c|c|c|c|c|c|c|c|c|}
\hline \multirow[b]{2}{*}{ Item } & \multicolumn{4}{|c|}{$\operatorname{Diet}^{1}$} & \multirow[b]{2}{*}{ SEM } & \multicolumn{3}{|c|}{$P$-value } \\
\hline & FGC & MGC & CGC & $\mathrm{SFC}$ & & Linear & Quadratic & Contrast $^{2}$ \\
\hline \multicolumn{9}{|l|}{ Digestibility, \% } \\
\hline $\mathrm{DM}$ & $77.2^{\mathrm{a}}$ & $72.4^{\mathrm{b}}$ & $73.2^{\mathrm{b}}$ & $78.2^{\mathrm{a}}$ & 1.16 & 0.05 & 0.04 & 0.01 \\
\hline $\mathrm{OM}$ & $80.6^{\mathrm{ab}}$ & $75.8^{\mathrm{c}}$ & $78.5^{\mathrm{b}}$ & $82.2^{\mathrm{a}}$ & 0.98 & 0.32 & 0.005 & 0.004 \\
\hline Starch & $98.4^{\mathrm{a}}$ & $97.2^{\mathrm{b}}$ & $97.8^{\mathrm{ab}}$ & $96.3^{\mathrm{c}}$ & 0.52 & 0.01 & 0.65 & 0.02 \\
\hline \multicolumn{9}{|l|}{ Feed efficiency } \\
\hline Milk/DMI & 1.83 & 1.91 & 1.85 & 1.89 & 0.07 & 0.87 & 0.09 & 0.37 \\
\hline $3.5 \% \mathrm{FCM} / \mathrm{DMI}$ & 1.55 & 1.58 & 1.60 & 1.65 & 0.05 & 0.24 & 0.79 & 0.02 \\
\hline ECM/DMI & 1.57 & 1.61 & 1.61 & 1.66 & 0.04 & 0.33 & 0.49 & 0.04 \\
\hline
\end{tabular}

${ }^{\mathrm{a}-\mathrm{c}}$ Least squares means within a row with different superscripts differ significantly $(P<0.05)$.

${ }^{1}$ Experimental diets contained fine-ground corn (FGC), medium-ground corn (MGC), coarse-ground corn (CGC), and steam-flaked corn (SFC).

${ }^{2}$ Contrast $P$-value $=$ effects of ground corn versus SFC. 


\section{DISCUSSION}

The study examined the effects of SFC and GC of different PS when fed to high-producing Holstein dairy cows.

\section{Effects of SFC Versus GC}

The lower MPS of GC compared with SFC caused the GC to almost entirely pass through the 8-mm sieve, resulting in greater mean PS of diets with SFC compared with GC. In agreement with these observations, Rafiee-Yarandi et al. (2019a) and Savari et al. (2018) reported that diets containing SFC had greater proportion of particles retained on an $8-\mathrm{mm}$ sieve and greater MPS compared with GC diets. Guidelines for PS of TMR for high producing dairy cows suggest having 2 to $8 \%$ of the particles retained on the upper sieve, 30 to $40 \%$ on the middle and lower sieves, and no more than $20 \%$ on the pan (Humer et al., 2018). In the current study, proportions of particles on the various sieves were within the suggested range for the SFC diets; however, GC diets had a lower proportion on the 8 -mm sieve (20\%) and a higher proportion on the pan (29.9\%; Table 3 ).

The effects of corn processing on DMI have been inconsistent; feeding SFC compared with GC decreased (Cooke et al., 2009; Savari et al., 2018; Rafiee-Yarandi et al., 2019a), increased (Yu et al., 1998; Bernard et al., 2004; Zhong et al., 2008), or had no effect (Cooke et al., 2008; Batistel et al., 2017) on DMI similar to the lack of treatment effect on DMI in the present study.

The majority of studies that investigated feed sorting in dairy cattle changed the forage components of the TMR (Miller-Cushon and DeVries, 2017), in contrast to the present study. Cows fed GC sorted against $>8$ $\mathrm{mm}$ particles 6 and $24 \mathrm{~h}$ after the morning feeding in comparison with cows fed SFC. In agreement with our results, Savari et al. (2018) and Rafiee-Yarandi et al. (2019a) showed that cows fed SFC sorted for particles on an 8-mm sieve more than cows fed GC.

Similar to the current experiment, Harvatine et al. (2002b) and Rafiee-Yarandi et al. (2019a) reported that eating and rumination time $(\mathrm{min} / \mathrm{d})$ were not different between cows fed SFC or GC. Additionally, Beauchemin et al. (2001) and Yang et al. (2001) reported that processing of barley grain had no effect on eating time and eating time per kilogram of DMI.

Despite similar chewing times, cows fed SFC diets had greater ruminal $\mathrm{pH}$ compared with cows fed GC, in agreement with the tendencies for lower total VFA and lower proportion of propionate and lower starch digestibility. In contrast, Zhong et al. (2008) and RafieeYarandi et al. (2019b) showed that ruminal pH was not affected by the substitution of SFC for GC. Because the increase in rumen $\mathrm{pH}$ was coupled with a slight decrease in total VFA and proportion of ruminal propionate and lower total-tract starch digestibility, it appears that less starch may have been digested in the rumen of cows fed SFC than those fed GC, which would have led to the increase in ruminal $\mathrm{pH}$. This shift in site of digestion may be related to the greater PS of the flaked corn compared with the GC. It should be mentioned that ruminal $\mathrm{pH}$ and fermentation was measured using only one spot sample in the present study, and thus fluctuations in $\mathrm{pH}$ over the 24-h day were not characterized. However, a previous comparison of rumenocentesis and indwelling rumenoreticular probes produced consistent ranking of cows based on $\mathrm{pH}$ (Nasrollahi et al., 2017); thus, the values reported in the present study are likely a good indication of potential treatment effects on rumen fermentation.

The greater total-tract apparent digestibility of DM and OM for SFC compared with GC diets is in accordance with other studies (Guyton et al., 2003; Burkholder et al., 2004; Cooke et al., 2009). Zhong et al. (2008) reported that apparent total-tract digestibility of $\mathrm{OM}$ and DM linearly decreased when GC was replaced by SFC in the diets; however, Dhiman et al. (2002) and Rafiee-Yarandi et al. (2019b) found that GC or SFC had no influence on DM digestibility. Although fiber digestibility was not measured in the present study, others reported greater digestibility of ADF (Yu et al., 1998; Lascano et al., 2016) and NDF (Mathew et al., 2011) in diets containing SFC compared with GC. It is possible that a shift in site of digestion of starch from the rumen to the intestine, and the elevation in ruminal $\mathrm{pH}$, led to an increase in fiber digestion, and consequently DM and OM digestibility, in the present study. In contrast to our results, apparent total-tract starch digestibility was increased by steam flaking of corn in comparison with GC in other studies (Dhiman et al., 2002; Guyton et al., 2003; Rafiee-Yarandi et al., 2019a). Flake density in those experiments was lower $(360 \mathrm{~g} / \mathrm{L})$ than in the current experiment $(400 \mathrm{~g} / \mathrm{L})$, which decreased the starch digestibility of SFC in the current experiment in comparison with GC. In confirmation of our results, Joy et al. (1997) reported that total-tract starch digestibility decreased from 94.4 to $85.1 \%$ as flake density increased from 310 to $390 \mathrm{~g} / \mathrm{L}$.

The lack of effect of grain processing method on milk production is consistent with the lack of effect on DMI. However, the increase in milk fat content with SFC compared with GC is consistent with lower ruminal starch digestibility and is in contrast to other studies where substitution of SFC for GC reduced milk fat content (Dhiman et al., 2002; Harvatine et al., 2002a; Savari et al., 2018; Rafiee-Yarandi et al., 2019b), or 
had no effect (Mathew et al., 2011). The flake density in the current experiment was slightly greater than recommended by Theurer et al. (1999; 400 vs. $360 \mathrm{~g} / \mathrm{L}$ ) for lactating dairy cows, and may have partially accounted for the lower ruminal and total-tract starch digestibility and greater milk fat content. When grain is extensively steam flaked, flake density is decreased and starch becomes more available to ruminal and totaltract digestion (Joy et al., 1997).

The greater efficiencies of milk production (FCM/ DMI and ECM/DMI) for cows fed the SFC diet compared with GC diets were due to numerically lower DMI, similar milk production, and higher milk fat content. These results contrast with the findings of other studies (Dhiman et al., 2002; Cooke et al., 2009), in which efficiency was not different between cows fed SFC or GC. In those experiments the flake density of SFC was less than in the current experiment (360 vs $400 \mathrm{~g} / \mathrm{L}$ ), and the milk fat content was lower in cows fed SFC. Joy et al. (1997) reported that rumen starch digestibility decreased from 44.8 to $27.2 \%$ as flake density increased from 310 to $390 \mathrm{~g} / \mathrm{L}$. The higher milk fat content due to greater flake density in the current experiment led to greater efficiency of cows fed SFC rather than GC. These results indicate that the optimum corn flake density in high-producing dairy cows may be greater than $360 \mathrm{~g} / \mathrm{L}$, although this recommendation requires further research.

\section{Effects of PS of GC}

A trend has been observed for dairy farms in Iran and elsewhere to reduce the PS of corn grain to increase lactational performance, mainly based on anecdotal evidence. Relevant published studies on optimum corn PS for high-producing dairy cows are lacking. The mean PS of the GC used in the present study is within the range (500 to $4,000 \mu \mathrm{m}$ ) reported in a meta-analysis conducted by Ferraretto et al. (2013).

As expected, GC diets had similar distribution of TMR particles retained on the 19- and 8-mm sieves because most of the GC was retained on the $1.18-\mathrm{mm}$ sieve and pan. Forage particles were uniform across treatments. When the mean PS of GC was increased, the particles retained on the $1.18-\mathrm{mm}$ sieve increased, whereas those retained on the pan decreased, which accounted for the greater mean PS of CGC compared with MGC and FGC diets.

We speculated that cows fed FGC might select larger particles of the TMR because of the need to attenuate the more rapid ruminal digestion of starch due to smaller PS of the grain; however, that was not the case. The lack of difference in sorting behavior due to PS of $\mathrm{GC}$ is consistent with the lack of difference in ruminal
$\mathrm{pH}$ among the GC diets. These results are consistent with those of De Nardi et al. (2014) who reported that mean ruminal $\mathrm{pH}$ was not different between fine and coarse GC.

The effect of PS of GC on DMI has been inconsistent in the literature. The lack of difference in DMI due to GC processing in the present study is similar to the findings of Callison et al. (2001), Remond et al. (2004), Fredin et al. (2015), and Brossillon et al. (2018), but contrast with the study of De Nardi et al. (2014) who reported that cows offered finely GC had greater DMI compared with those offered coarse GC. According to Allen (2000), stimulating the distention receptors located in the rumen epithelium and increasing hepatic oxidation can decrease DMI. In the current experiment, the minimal difference in ration PS would not have changed distention of the rumen, and the similar propionate concentration among GC treatments would not have changed hepatic oxidation.

The differences in PS of GC did not affect chewing activity, which is in agreement with Knowlton et al. (1996). The lack of effect of GC PS on chewing, combined with a lack of effect on ruminal $\mathrm{pH}$ and fermentation, suggests that ruminal digestibility also did not differ, although site of digestion was not measured. Similarly, some other previous studies reported that different PS of GC had no effects on VFA concentrations (Knowlton et al., 1996, 1998; Callison et al., 2001; Remond et al., 2004). However, Fredin et al. (2015) showed that cows fed a finely GC diet had greater ruminal propionate, lower acetate:propionate ratio, and lower rumial $\mathrm{pH}$ than cows fed a coarse GC diet. Although apparent starch, DM, and OM digestibilities were greater for FGC compared with MGC, GC PS had an inconsistent effect on total-tract digestibility. Previous studies reported that as corn PS decreased, starch (Fredin et al., 2015; Brossillon et al., 2018), DM (Brossillon et al., 2018), and OM (Callison et al., 2001; Remond et al., 2004; Brossillon et al., 2018) digestibility increased, although other studies (San Emeterio et al., 2000; De Nardi et al., 2014) found no relationship. In agreement with our results, the meta-analysis of Ferraretto et al. (2013) reported that apparent total-tract digestibilities of DM, OM, and starch decreased as dry corn grain PS increased, but NDF digestibility was not affected. As reported by Cao et al. (2008), smaller corn particles increase the surface area for microbial adhesion, which leads to fast and complete ruminal degradation, which increases total-tract digestibility.

Although PS of GC did not affect milk production, the quadratic increase in milk protein content and quadratic decrease in milk fat content of MGC compared with FGC and CGC is somewhat difficult to explain, although it is consistent with the observed quadratic 
decrease in starch, OM, and DM digestibility for MGC. Others have reported that PS of corn did not affect milk production and milk fat content (Callison et al., 2001; Fredin et al., 2015; Brossillon et al., 2018). Remond et al. (2004) studied different PS of corn grain (0.7, 1.8 , and $3.7 \mathrm{~mm}$ ) and found that cows fed a diet with 0.7-mm corn grain had a tendency to increase milk production. In the present study, FGC and CGC differed in mean PS by $350 \mu \mathrm{m}$. Thus, the greater difference in corn grain PS reported by Knowlton et al. (1996; 2,438 $\mu \mathrm{m})$ and Remond et al. (2004; 2,938 $\mu \mathrm{m})$ may explain the observed discrepancies among the studies. Firkins et al. (2001) reported that milk fat and protein contents were greater for coarse CG compared with fine CG, whereas Ferraretto et al. (2013) reported that milk fat and protein content were unaffected by PS of CG. In the current experiment, fat content was lower for the MGC diet than the other diets (2.48 vs. $2.65 \%$ ).

Similar DMI and milk yields resulted in similar efficiencies among the GC diets that varied in PS. In agreement with this observation, Callison et al. (2001) and Fredin et al. (2015) reported that PS of corn grain had no effect on efficiency (milk yield/DMI, FCM/ DMI, and ECM/DMI). The range in corn PS (from 0.73 to $1.08 \mathrm{~mm}$ ) in the present study is similar to the variation typically observed among Iranian dairy farms. However, this range may be less than the relative differences between PS used in some other studies, which may have limited the effect of treatment on the variables studied. The meta-analysis conducted by Ferraretto et al. (2013) reported no differences in DMI, milk yield, content and yield of milk components, and feed efficiency in dairy cows when the mean PS of corn differed by a minimum of $500 \mu \mathrm{m}$ to a maximum of $3,500 \mu \mathrm{m}$. Remond et al. (2004) reported that grinding to $<1.5 \mathrm{~mm}$ for floury corn hybrids, and $<1 \mathrm{~mm}$ for vitreous corn types improved starch digestibility in the total tract compared with grinding more coarsely. Callison et al. (2001) noted that a mean PS of $\leq 1 \mathrm{~mm}$ was required to maximize the total-tract nonstructural carbohydrate digestibility of GC. Overall, data from the current experiment when combined with other research studies suggest that the final PS of GC has little effect on high-producing dairy cows once the mean PS after grinding is $\leq 1 \mathrm{~mm}$.

\section{CONCLUSIONS}

Under the conditions of this experiment, steam flaking and grinding corn grains to different PS was found to have no effects on DMI, production of milk, 3.5\% FCM, ECM, fat, or the content of milk protein. However, milk fat content was greater for diets containing SFC versus GC, whereas milk fat content tended to quadratically decrease with decreasing PS of GC. Feeding SFC and corn finely ground to a mean PS of 0.73 $\mathrm{mm}$ improved DM digestibility; however, cows fed SFC had lower starch digestibility than cows fed GC. Ruminal $\mathrm{pH}$ increased, whereas total VFA concentration decreased with SFC compared with GC diets, indicating a possible shift in site of starch digestion from the rumen to the intestine due to flaking. Feed efficiency (FCM/ DMI) was greater for diets containing SFC versus GC. Overall, this study indicated that use of SFC with 400 g/L density can improve FCM/DMI, DM digestibility, and ruminal conditions, thereby enhancing milk fat content. For high-producing dairy cows $(>45 \mathrm{~kg} / \mathrm{d})$ with high DMI $(>24 \mathrm{~kg} / \mathrm{d})$, corn flaking may improve rumen health and milk fat content without decreasing milk yield.

\section{ACKNOWLEDGMENTS}

The study was funded by the Isfahan University of Technology (Isfahan, Iran). Appreciation is extended to staff at the Lavark farm and the research and teaching unit (Isfahan University of Technology, Isfahan, Iran). Thanks to Azam Mohammadi Mehr, Hosein Saeidi, and other students (Isfahan University of Technology, Isfahan, Iran) for helping to conduct this experiment. The authors have not stated any conflicts of interest.

\section{REFERENCES}

Allen, M. S. 2000. Effects of diet on short-term regulation of feed intake by lactating dairy cattle. J. Dairy Sci. 83:1598-1624. https:// doi.org/10.3168/jds.S0022-0302(00)75030-2.

ANSI (American National Standards Institute). 1995. Method of determining and expressing fineness of feed material by sieving. Method S424.1. Page 461 in ASAE Standards 1995. American Society of Agricultural Engineers, St. Joseph, MI.

AOAC International. 2002. Official Methods of Analysis. 17th ed. AOAC International, Arlington, VA.

ASABE. 2003. Methods of determining and expressing fineness of feed materials by sieving. Pages 202-205. Standard no. S319.3. American Society of Agricultural and Biological Engineers, St. Joseph, MI.

Bal, M. A., R. D. Shaver, A. G. Jirovec, K. J. Shinners, and J. G. Coors. 2000. Crop processing and chop length of corn silage: Effects on intake, digestion, and milk production by dairy cows. J. Dairy Sci. 83:1264-1273. https://doi.org/10.3168/jds.S0022 -0302(00)74993-9.

Batistel, F., J. de Souza, and F. A. P. Santos. 2017. Corn grain-processing method interacts with calcium salts of palm fatty acids supplementation on milk production and energy balance of earlylactation cows grazing tropical pasture. J. Dairy Sci. 100:53435357. https://doi.org/10.3168/jds.2016-12503.

Beauchemin, K. A., and W. Z. Yang. 2005. Effects of physically effective NDF on intake, chewing activity, and ruminal acidosis for dairy cows fed diets based on corn silage. J. Dairy Sci. 88:21172129. https://doi.org/10.3168/jds.S0022-0302(05)72888-5.

Beauchemin, K. A., W. Z. Yang, and L. M. Rode. 2001. Effects of barley grain processing on the site and extent of digestion of beef feedlot finishing diets. J. Anim. Sci. 79:1925-1936. https://doi .org/10.2527/2001.7971925x. 
Bernard, J. K., P. T. Chandler, J. W. West, A. H. Parks, H. A. Amos, M. A. Froetschel, and D. S. Trammell. 2004. Effect of supplemental L-lysine- $\mathrm{HCl}$ and corn source on rumen fermentation and amino acid flow to the small intestine. J. Dairy Sci. 87:399-405. https://doi.org/10.3168/jds.S0022-0302(04)73179-3.

Broderick, G., and J. Kang. 1980. Automated simultaneous determination of ammonia and total amino acids in ruminal fluid and in vitro media. J. Dairy Sci. 63:64-75. https://doi.org/10.3168/jds .S0022-0302(80)82888-8.

Brossillon, V., S. F. Reis, D. C. Moura, J. G. B. Galvão Jr., A. S. Oliveira, C. Côrtes, and A. F. Brito. 2018. Production, milk and plasma fatty acid profile, and nutrient utilization in Jersey cows fed flaxseed oil and corn grain with different particle size. J. Dairy Sci. 101:2127-2143. https://doi.org/10.3168/jds.2017-13478.

Burkholder, K. M., A. D. Guyton, J. M. McKinney, and K. F. Knowlton. 2004. The effect of steam flaked or dry ground corn and supplemental phytic acid on nitrogen partitioning in lactating cows and ammonia emission from manure. J. Dairy Sci. 87:2546-2553. https://doi.org/10.3168/jds.S0022-0302(04)73379-2.

Callison, S., J. Firkins, M. Eastridge, and B. Hull. 2001. Site of nutrient digestion by dairy cows fed corn of different particle sizes or steam-rolled. J. Dairy Sci. 84:1458-1467. https://doi.org/10.3168/ jds.S0022-0302(01)70179-8.

Cao, Z. J., S. L. Li, J. J. Xing, M. Ma, and L. L. Wang. 2008. Effects of maize grain and lucerne particle size on ruminal fermentation, digestibility and performance of cows in midlactation. J. Anim. Physiol. Anim. Nutr. (Berl.) 92:157-167. https://doi.org/10.1111/ j.1439-0396.2007.00721.x.

Chen, K. H., J. T. Huber, C. B. Theurer, J. Simas, F. Santos, S. C. Chan, and R. S. Swingle. 1995. Effect of substituting steamflaked sorghum for concentrate on lactation and digestion in dairy cows. J. Dairy Sci. 78:362-367. https://doi.org/10.3168/jds.S0022 -0302(95)76644-9.

Cooke, K., J. Bernard, and J. West. 2008. Performance of dairy cows fed annual ryegrass silage and corn silage with steam-flaked or ground corn. J. Dairy Sci. 91:2417-2422. https://doi.org/10.3168/ jds.2007-0715.

Cooke, K., J. Bernard, and J. West. 2009. Performance of lactating dairy cows fed ryegrass silage and corn silage with ground corn, steam-flaked corn, or hominy feed. J. Dairy Sci. 92:1117-1123. https://doi.org/10.3168/jds.2008-1481.

De Nardi, R., G. Marchesini, A. L. Stefani, A. Barberio, I. Andrighetto, and S. Segato. 2014. Effect of feeding fine maize particles on the reticular $\mathrm{pH}$, milk yield and composition of dairy cows. J. Anim. Physiol. Anim. Nutr. (Berl.) 98:504-510. https://doi.org/ 10.1111/jpn.12099.

Dhiman, T., M. Zaman, I. MacQueen, and R. Boman. 2002. Influence of corn processing and frequency of feeding on cow performance. J. Dairy Sci. 85:217-226. https://doi.org/10.3168/jds.S0022 -0302(02)74070-8.

Ferraretto, L., P. Crump, and R. Shaver. 2013. Effect of cereal grain type and corn grain harvesting and processing methods on intake, digestion, and milk production by dairy cows through a metaanalysis. J. Dairy Sci. 96:533-550. https://doi.org/10.3168/jds $.2012-5932$

Firkins, J. L., M. L. Eastridge, N. R. St-Pierre, and S. M. Noftsger. 2001. Effects of grain variability and processing on starch utilization by lactating dairy cattle. J. Anim. Sci. 79(E. Suppl.):E218E238.

Fredin, S. M., L. Ferraretto, M. Akins, S. Bertics, and R. Shaver. 2015. Effects of corn-based diet starch content and corn particle size on lactation performance, digestibility, and bacterial protein flow in dairy cows. J. Dairy Sci. 98:541-553. https://doi.org/10.3168/jds $.2014-8502$

Guyton, A. D., J. McKinney, and K. Knowlton. 2003. The effect of steam-flaked or dry ground corn and supplemental phytic acid on phosphorus partitioning and ruminal phytase activity in lactating cows. J. Dairy Sci. 86:3972-3982. https://doi.org/10.3168/jds .S0022-0302(03)74008-9.

Harvatine, D. I., J. L. Firkins, and M. Eastridge. 2002a. Whole linted cottonseed as a forage substitute fed with ground or steam-flaked corn: Digestibility and performance. J. Dairy Sci. 85:1976-1987. https://doi.org/10.3168/jds.S0022-0302(02)74274-4.

Harvatine, D. I., J. Winkler, M. Devant-Guille, J. Firkins, N. StPierre, B. Oldick, and M. Eastridge. 2002b. Whole linted cottonseed as a forage substitute: Fiber effectiveness and digestion kinetics. J. Dairy Sci. 85:1988-1999. https://doi.org/10.3168/jds.S0022 -0302(02)74275-6.

Humer, E., R. M. Petri, J. R. Aschenbach, B. J. Bradford, G. B. Penner, M. Tafaj, K. H. Südekum, and Q. Zebeli. 2018. Practical feeding management recommendations to mitigate the risk of subacute ruminal acidosis in dairy cattle. J. Dairy Sci. 101:872-888. https://doi.org/10.3168/jds.2017-13191.

Iranian Council of Animal Care. 1995. Guide to the Care and Use of Experimental Animals. Vol. 1. Isfahan University of Technology, Isfahan, Iran.

Joy, M. T., E. J. DePeters, J. G. Fadel, and R. A. Zinn. 1997. Effects of corn processing on the site and extent of digestion in lactating cows. J. Dairy Sci. 80:2087-2097. https://doi.org/10.3168/jds .S0022-0302(97)76154-X.

Knowlton, K. F., M. Allen, and P. Erickson. 1996. Lasalocid and particle size of corn grain for dairy cows in early lactation. 1. Effect on performance, serum metabolites, and nutrient digestibility. J. Dairy Sci. 79:557-564. https://doi.org/10.3168/jds.S0022 -0302(96)76400-7.

Knowlton, K. F., B. Glenn, and R. Erdman. 1998. Performance, ruminal fermentation, and site of starch digestion in early lactation cows fed corn grain harvested and processed differently. J. Dairy Sci. 81:1972-1984. https://doi.org/10.3168/jds.S0022 -0302(98)75771-6.

Kononoff, P. J., A. J. Heinrichs, and D. R. Buckmaster. 2003. Modification of the Penn State forage and total mixed ration particle separator and the effects of moisture content on its measurements. J. Dairy Sci. 86:1858-1863. https://doi.org/10.3168/jds.S0022 -0302(03)73773-4.

Kotarski, S. F., R. D. Waniska, and K. K. Thurn. 1992. Starch hydrolysis by the ruminal microflora. J. Nutr. 122:178-190. https://doi .org/10.1093/jn/122.1.178.

Lascano, G. J., M. Alende, L. E. Koch, and T. C. Jenkins. 2016. Changes in fermentation and biohydrogenation intermediates in continuous cultures fed low and high levels of fat with increasing rates of starch degradability. J. Dairy Sci. 99:6334-6341. https:// doi.org/10.3168/jds.2016-11032.

Leonardi, C., and L. Armentano. 2003. Effect of quantity, quality, and length of alfalfa hay on selective consumption by dairy cows. J. Dairy Sci. 86:557-564. https://doi.org/10.3168/jds.S0022 $-0302(03) 73634-0$

Lykos, T., and G. A. Varga. 1995. Effects of processing method on degradation characteristics of protein and carbohydrate sources in situ. J. Dairy Sci. 78:1789-1801. https://doi.org/10.3168/jds .S0022-0302(95)76804-7.

Mason, M., B. Gleason, and G. Rokey. 1982. A new method for determining degree of cook. Pages 123-124 in Proc. Am. Assoc. Cereal Chem. Conf., 67th Annual Meeting, San Antonio, TX.

Mathew, B., M. L. Eastridge, E. R. Oelker, J. L. Firkins, and S. K. R. Karnati. 2011. Interactions of monensin with dietary fat and carbohydrate components on ruminal fermentation and production responses by dairy cows. J. Dairy Sci. 94:396-409. https://doi.org/ 10.3168/jds.2010-3580

McAllister, T., H. Bae, G. Jones, and K. Cheng. 1994. Microbial attachment and feed digestion in the rumen. J. Anim. Sci. 72:30043018. https://doi.org/10.2527/1994.72113004x.

McNiven, M. A., M. R. Weisbjerg, and T. Hvelplund. 1995. Influence of roasting or sodium hydroxide treatment of barley on digestion in lactating cows. J. Dairy Sci. 78:1106-1115. https://doi.org/10 .3168/jds.S0022-0302(95)76727-3.

Miller-Cushon, E. K., and T. J. DeVries. 2017. Feed sorting in dairy cattle: Causes, consequences, and management. J. Dairy Sci. 100:4172-4183. https://doi.org/10.3168/jds.2016-11983.

Nasrollahi, S. M., A. Zali, G. R. Ghorbani, M. Moradi, and M. Heydari. 2017. Variability in susceptibility to acidosis among high producing mid-lactation dairy cows is associated with rumen $\mathrm{pH}$, 
fermentation, feed intake, sorting activity, and milk fat percentage. Anim. Feed Sci. Technol. 228:72-82. https://doi.org/10.1016/ j.anifeedsci.2017.03.007.

Nordlund, K., and E. Garrett. 1994. Rumenocentesis: A technique for collecting rumen fluid for the diagnosis of subacute rumen acidosis in dairy herds. Bov. Pract. 28:109-119.

NRC. 2001. Nutrient Requirements of Dairy Cattle. 7th rev. ed. Natl. Acad. Sci., Washington, DC.

Oliveira, J. S., J. T. Huber, D. Ben-Ghedalia, R. S. Swingle, C. B. Theurer, and M. Pessarakli. 1993. Influence of sorghum grain processing on performance of lactating dairy cows. J. Dairy Sci. 76:575-581. https://doi.org/10.3168/jds.S0022-0302(93)77377-4.

Owens, F. N., and R. A. Zinn. 2005. Corn grain for cattle: Influence of processing on site and extent of digestion. Pages 78-85 in Southwest Nutr. Conf., Univ. of Arizona.

Rafiee-Yarandi, H., M. Alikhani, G. R. Ghorbani, M. Heydari, and P. Rezamand. 2019a. Dietary protein level and corn processing method: Intake, digestibility, and feeding behavior of lactating dairy cows. Livest. Sci. 221:19-27. https://doi.org/10.1016/j.livsci 2019.01.001.

Rafiee-Yarandi, H., M. Alikhani, G. R. Ghorbani, M. Heydari, and P. Rezamand. 2019b. Dietary protein level and corn processing method: Lactation performance, milk fatty acid composition, rumen and blood parameters of lactation dairy cows. Livest. Sci. 221:95-104. https://doi.org/10.1016/j.livsci.2019.01.019.

Remond, D., J. Cabrera-Estrada, M. Champion, B. Chauveau, R. Coudure, and C. Poncet. 2004. Effect of corn particle size on site and extent of starch digestion in lactating dairy cows. J. Dairy Sci. 87:1389-1399. https://doi.org/10.3168/jds.S0022-0302(04)73288 $-9$.

San Emeterio, F., R. B. Reis, W. E. Campos, and L. D. Satter. 2000. Effect of coarse or fine grinding on utilization of dry or ensiled corn by lactating dairy cows. J. Dairy Sci. 83:2839-2848. https:// doi.org/10.3168/jds.S0022-0302(00)75184-8.

Savari, M., M. Khorvash, H. Amanlou, G. R. Ghorbani, E. Ghasemi, and M. Mirzaei. 2018. Effects of rumen-degradable protein: rumen-undegradable protein ratio and corn processing on production performance, nitrogen efficiency, and feeding behavior of Holstein dairy cows. J. Dairy Sci. 101:1111-1122. https://doi.org/10.3168/ jds.2017-12776.
Svihus, B., A. K. Uhlen, and O. M. Harstad. 2005. Effect of starch granule structure, associated components and processing on nutritive value of cereal starch: A review. Anim. Feed Sci. Technol. 122:303-320. https://doi.org/10.1016/j.anifeedsci.2005.02.025.

Theurer, C., J. Huber, A. Delgado-Elorduy, and R. Wanderley. 1999. Summary of steam-flaking corn or sorghum grain for lactating dairy cows. J. Dairy Sci. 82:1950-1959. https://doi.org/10.3168/ jds.S0022-0302(99)75431-7.

Tyrrell, H. F., and J. T. Reid. 1965. Prediction of the energy value of cow's milk. J. Dairy Sci. 48:1215-1223. https://doi.org/10.3168/ jds.S0022-0302(65)88430-2.

Van Keulen, J., and B. Young. 1977. Evaluation of acid-insoluble ash as a natural marker in ruminant digestibility studies. J. Anim. Sci. 44:282-287. https://doi.org/10.2527/jas1977.442282x.

Van Soest, P. J., J. Robertson, and B. Lewis. 1991. Methods for dietary fiber, neutral detergent fiber, and nonstarch polysaccharides in relation to animal nutrition. J. Dairy Sci. 74:3583-3597. https:/ /doi.org/10.3168/jds.S0022-0302(91)78551-2.

Wilson, R., T. Overton, and J. Clark. 1998. Effects of Yucca shidigera extract and soluble protein on performance of cows and concentrations of urea nitrogen in plasma and milk. J. Dairy Sci. 81:10221027. https://doi.org/10.3168/jds.S0022-0302(98)75664-4.

Yang, W. Z., K. A. Beauchemin, and L. M. Rode. 2001. Effects of grain processing, forage to concentrate ratio, and forage particle size on rumen $\mathrm{pH}$ and digestion by dairy cows. J. Dairy Sci. 84:2203-2216. https://doi.org/10.3168/jds.S0022-0302(01)74667-X.

Yu, P., J. Huber, F. Santos, J. Simas, and C. Theurer. 1998. Effects of ground, steam-flaked, and steam-rolled corn grains on performance of lactating cows. J. Dairy Sci. 81:777-783. https://doi.org/ 10.3168/jds.S0022-0302(98)75634-6.

Zhong, R., J. Li, Y. Gao, Z. Tan, and G. Ren. 2008. Effects of substitution of different levels of steam-flaked corn for finely ground corn on lactation and digestion in early lactation dairy cows. J. Dairy Sci. 91:3931-3937. https://doi.org/10.3168/jds.2007-0957.

Zhu, L., C. Jones, Q. Guo, L. Lewis, C. R. Stark, and S. Alavi. 2016. An evaluation of total starch and starch gelatinization methodologies in pelleted animal feed. J. Anim. Sci. 94:1501-1507. https:// doi.org/10.2527/jas.2015-9822. 